\title{
7
}

\section{Breeders and owners}

\section{Breeders}

England, particularly northern England, was the original home of the Ethoroughbred horse, and thoroughbred breeding was a national industry of great value. In former centuries England had maintained a global supremacy, even though Irish, French and American horses were occasionally successful in major races. Between the wars England struggled to retain its lead. Nevertheless a firm belief that Britain was best, and that British breeding was superior, still dominated the cultural thinking of British breeders. Edward Moorhouse, secretary of the Society for the Encouragement of Thoroughbred Breeding, claimed that 'England is the home of the thoroughbred and it is only here that he can retain his perfection ... it is vital to maintain our superiority..$^{1} \mathrm{~A}$ highly affirmative image of British stud produce was also maintained by the racing press, and some correspondents, such as 'Audax' (Arthur Portman) or 'Mandanko' (Professor Robertson) were breeding experts. All the major racing papers published descriptions of their correspondents' visits to racing studs. Descriptions of the horses included colour, breeding lines, shape, conformation and similar details and were always couched positively. The foals described in 'a round of the Burton Agnes Stud' in 1935, for example, were variously of 'great symmetry and superb quality', 'very smart', 'strong and active', 'good', 'shapely' and 'neat'. The Lordship stud horses were variously 'lengthy', 'handsome', 'active', 'compact', 'well balanced', a 'good mover', 'fine', 'rich' and 'free-moving. ${ }^{2}$ Poorer ones were presumably not mentioned.

The ideal for all breeders was to breed stamina and speed in their horses, but Britain, with its high proportion of 2-year-old racers, largely bred for speed at the expense of stamina. English breeders almost never imported mares or stallions for breeding purposes, whilst exporting some of their best stock. One result of this was that between the wars foreign horses began to achieve an 
increasing proportion of successes in those British races requiring more stamina. New strains of outstanding prepotence were being established in France, America, Italy, Australia and South America. There were, for example, French successes in both the Cambridgeshire and Cesarewitch in 1938. British excuses were always found. When statistical articles appeared in the Americanpublished Thoroughbred Record (Lexington, Kentucky) which appeared to suggest that English thoroughbreds were becoming inferior to those overseas, they were dismissed slightingly as 'ridiculous', 'based on false premises' and 'futile vapourings' ${ }^{3}$

Breeders provided the thoroughbreds for flat racing, and were therefore indispensable. But although most of them bred for sale, and saw themselves as commercial businesses, the extent to which some actually made a profit was problematical. They did not support racing financially, but rather sought to gain from it by selling their stock. Breeders varied in their background, but a significant minority had titles or military rank. Breeding was an avenue which upper-class women were beginning to enter after the war and through the 1920s and 1930s. By 1938, Lady Beryl Groves, Lady James Douglas, Lady Wentworth and Lady Barbara Scott all sold five or more yearlings at the July Newmarket sales or the September Doncaster sales, which were the Mecca of yearling vendors and buyers. Lady Wentworth was sufficiently knowledgeable to write a book on breeding. ${ }^{4}$ A majority of smaller breeders were farmers, and for many thoroughbreds were a sideline. If they paid their way, well and good; if they produced a profit, better still. Trainers with spare stable capacity might also become involved in breeding on a small scale, while veterinary surgeons sometimes conducted a stud. Jock Crawford, for example, son of a blacksmith, who had trained as a veterinary surgeon in Glasgow, became interested in racing and breeding in India, and became involved in the British Bloodstock Agency and the Glasgow Stud at Enfield.

The number of yearlings sold by each breeder varied. At the earlier Newmarket July sales, small breeders, selling one or two yearlings, usually represented between 50 and 60 per cent of the vendors. This was probably an attempt to cash in on their assets as soon as possible. At the later Doncaster sales this figure was lower, usually around 40 per cent. Few breeders sold more than ten yearlings. In 1938 only the Aga Khan, Lord Furness, Mr J. W. Harris and four commercial studs, the Worksop Manor Stud, the Exning Stud, the Sledmere Stud and the Ballykisteen Stud in Ireland, sold so many.

Some breeders were breeder-owners, breeding and racing their own horses, and prepared to trade potential profit for the pleasure of ownership. Their 
motives varied, but some at least were less concerned with success per se than with trying to improve the breed. The duke of Westminster, for example, cared little for racing, but devoted 'his time, attention and money to breeding bloodstock' at his Eaton Hall Stud. ${ }^{5}$ Kingsclere Ltd, a training stable syndicate in which he and the duke of Portland were involved, was not used between 1919 and 1934. Despite George V's large Wolferton Stud, of about twenty mares, its stock were only rarely successful on the racecourse, partly because for prestige reasons the king's racing manager and trainer in the early 1920s entered them at races where their majesties were more likely to be present. Even a change of trainer and racing manager had little effect. Indeed in 1927 and 1928 none of the foals bred at the king's stud won a single race. Yet the king had a very deeprooted interest in breeding and the welfare of his young stock. On his arrival at Sandringham, his first tour of inspection was to go carefully round the stud. He enjoyed visiting the mares and young stock, and derived great pleasure from showing off to friends his leading stallion, Friar Marcus, at stud in Egerton. ${ }^{6}$ By contrast George VI knew much less about breeding. Others bred because it was a 'traditional' part of upper-class life. At Wynyard Park, in County Durham, there had been interest in racing by successive Lord Londonderrys for many generations, and they continued to breed there, with only limited success, up to 1924. After 1933 they indulged their interest in breeding through membership of Apelle Ltd, a horse syndicate. ${ }^{7}$

Breeding provided great pleasure to many of those involved. To John Crawford, for example, 'his love and life was the throughbred. It was a joy to him to be able to dispense his unusual heritage to those whom he thought he could aid, or who desired his assistance'. ${ }^{8}$ William Fawcett, the hunting and racing editor of The Field, clearly really enjoyed his 'joyous days in sun-lit paddock and shaded stud farm', amongst many 'friends of long standing'. He felt that 'to see the horses that you have bred yourself, to make plans for the mating of your mares, to weigh up and examine the winning strains in the different bloods, to find out that your theories have worked out correctly - there is a joy in all these things that increases with the passing of the years'. 'Mrs Edward Clayton had a few horses in training, but preferred breeding: 'her heart and mind love chiefly the mare, the yearling, the foal and the sires at stud'. ${ }^{10}$

Some leading owner-breeders were very much involved in the study of breeding. At Lord Rosebery's stud, for instance, matings were made on his orders, not his manager's. For leading owner-breeders there was an element of competition to prove that their theories of breeding worked. Scientific advances in breeding theory came only slowly. Lord Astor claimed that he 
'bred racehorses as some men breed other sorts of livestock or plants' and liked to test his theories 'against the best that others could produce. ${ }^{11}$ The Aga Khan's racing success was not just based on lavish investment and superbly equipped studs, and ability to pick good managers, trainers and jockeys. It was underpinned by an excellent knowledge of breeding, and a breeding philosophy based partly on mixing bloodlines of great stallions in carefully calculated percentages of inbreeding and outbreeding. ${ }^{12}$ Inbreeding increased the influence of the ancestor to whom a breeder inbred. Other breeders, such as C. R. Acton, attached greater importance to the female line. ${ }^{13}$ Lord Wavertree, a member of a well-known Lancashire brewing family, who had also made a profound study of breeding, attached little importance to the sire and great importance to his mares, and went further still, applying astrology to his racing and breeding interests. Breeders could follow a wide variety of breeding systems and theories: the stamina index, the Vuillier dosage system, the Bruce Lowe figure system and blood affinity all had their supporters. Most theories used data from the limited numbers of successful racehorses, not the far more plentiful bad ones or those offspring which never saw a racecourse. ${ }^{14}$

The breeding industry had always been economically risky and although it largely rode out the economic volatility of the 1920s and 1930s the period was fraught with anxiety for breeders, even though the drastic weeding out of useless horses that took place during the 1914-18 War had positive effects on the breeding stock. As the 1938 News Chronicle Racing Annual admitted, 'it is a hazardous game, this breeding'. ${ }^{15}$ Least concerned were owners of top, fashionable, stallions whose offspring were winning races with substantial prize money, although stallion fees were taxed until Lord Rosebery succeeded in changing the law. For this minority breeding was more lucrative, although some kept their best yearlings rather than selling them. For others who wished to put their mares to a good stallion prices rose after the war. By 1936 the 'covering' of a mare by any of the top eight stallions would cost its owner over $£ 400$; in 1914 only three stallions had been priced so high. A top stallion was rarely allowed to cover more than forty mares a season, and in the mid-1930s the minimum covering fee charged for any of the top one hundred or so stallions was about 45 guineas, and a maximum around 500 guineas. There were around two hundred stallions appearing annually in the main section of the Register of Thoroughbred Stallions, and many more of minor importance in abbreviated form in the appendix. ${ }^{16}$

Breeding studs were scattered throughout the country, not just on rich estates, and many such as the Glasgow stud farm near Enfield, for example, run by the British Bloodstock Agency, were in locations which had been used for 
Table 7.I Percentage of stallions at different stud fees in guineas, 1920-39

\begin{tabular}{lccccc}
\hline & $\begin{array}{c}\text { No.in } \\
\text { sample }\end{array}$ & $\begin{array}{c}\mathbf{2 5 g} \text { or less } \\
\%\end{array}$ & $\begin{array}{c}\mathbf{2 6 - 1 0 0 g} \\
\%\end{array}$ & $\begin{array}{c}\text { 101-200g } \\
\%\end{array}$ & $\begin{array}{c}\text { more than } \\
\mathbf{2 0 0 g} \\
\%\end{array}$ \\
\hline 1920 & 326 & 71 & 21 & 1 & 6 \\
1929 & 223 & 56 & 29 & 4 & 12 \\
1939 & 274 & 53 & 33 & 8 & 7 \\
\hline
\end{tabular}

Source: Adapted from Wray Vamplew The Turf (London: Allen Lane, 1976), p. 193

many generations. There were areas of particular concentration, with the Newmarket area and the regions around York and Bedale being particularly significant. Many stayed in the same family for generations. Some changed hands regularly, but were rarely profitable. Lord St David spent more than $£ 30,000$ on his Newmarket Lordship stud in the ten years he held it but it could not attract an offer of $£ 30,000$ in 1936 . $^{17}$

Studs came under the category of agriculture. The routines of looking after the brood mares, and dealing with covering, foaling and rearing were attractive to some workers, and it was a semi-skilled occupation. Most commercial studs employed a specialised stud groom, who received accommodation, keep and salary, together with a 1-guinea fee paid by the owner of each mare covered, to ensure covering was successful. Stud grooms managed the stud, and often advised owners which foals to keep and which should be drafted and sold. Most studfarms employed grooms and stable lads too, some from long-standing studfarm families. When John Lancaster joined a Newmarket stud, his father and uncle already worked there. ${ }^{18}$

Because owners could make money during a stallion's potent life, top stallions realised high prices. The great stayer Solario was sold for $£ 49,350$ on his owner's death in 1932, and maintained a stud fee of $£ 525$ thereafter, becoming champion sire in 1937. The Beech House Stud in Newmarket, owned by the bookmaker Martin Benson, paid $£ 50,000$ for Derby winner Windsor Lad in 1934 , and $£ 60,000$ for Nearco, the Italian champion and winner of the Grand Prix de Paris, in 1938. ${ }^{19}$

Purchase could be risky. Nearco became a leading sire but Windsor Lad did not last long at stud. Call Boy, the 1926 Derby winner, cost $£ 60,000$ but proved virtually sterile, with scarcely any successful offspring. However these were excessive prices. Good stallions between the wars more usually sold for between 
$£ 7,000$ and $£ 16,000$. Mares were a little cheaper. Mrs Chester Beatty paid $£ 12,600$ for a single mare that proved disappointing at stud, and the highest price paid during this period was $£ 18,700$. Lord D'Abernon sold five mares for $£ 33,075$ in the generally depressed market of 1929 .

Not all breeders sold their stock. Traditionally the upper classes often kept their good yearlings to race. Top breeders such as the seventeenth earl of Derby or the Aga Khan, who could afford to have their mares covered by top stallions, were regularly successful in classic events with horses of their own breeding between the wars, although this was in part also a result of employing expert staff. Lord Savile (d.1931) carried on a small stud at Rufford, some seasons sending his yearlings to Doncaster, other times sending them for training.

A few of these rich breeders, who had access to the best stallions, mated their mares with their own stallions, but many sent nearly all their mares to stallions they did not own, paying high subscription fees for the privilege. A stallion was chosen for a variety of reasons, including the success of his progeny, conformation, temperament, speed or stamina, inbreeding or outcrossing, the blending of particular bloodlines, or just current fashion. Breeders were made well aware of their successes and failures. The racing press annually published lists of winning breeding stallions and mares based on the amount of stakes won at races that year by their offspring.

Prices of yearlings reflected both their perceived current market values, and attitudes amongst the wealthier classes who could afford the conspicuous consumption of racehorse purchase. Value was in part a product of the amount owners could afford to invest, and reflected current economic situations. It was also dependent in part on the number of yearlings available and this was linked to breeder confidence some two years before. The perceived annual quality of yearlings was also variable. So was the amount of prize money offered by courses, and this also influenced purchasers. Fashionably bred yearlings usually cost far more, and were bought by the richest owners. Lord Glanley bred more horses than he required but still sometimes bought two or three high-priced yearlings, as did Lord Woolavington. Indeed, the highest price paid for a yearling in the 1920s auction sales was 14,500 guineas paid in 1920 by Lord Glanely for Blue Ensign from the Sledmere Stud; the highest in the 1930s the 15,000 guineas paid by Miss Dorothy Paget for the colt Colonel Payne. However, some yearlings were sold privately by breeders. In 1926 the Aga Khan

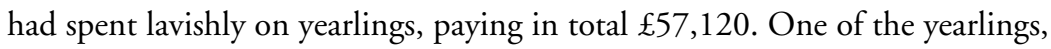
Feridoon, was purchased from the National Stud for $£ 17,000$ but was a complete failure as a racehorse and was eventually sold in France for about $£ 13$. This 
illustrates the point that potential racing success was a lottery, and not always related to price. Lord Glanley won the 1919 Derby with a horse bought for $£ 470 .^{20}$

Breeding was a high-status occupation, but the high prices paid for a few top-class yearlings concealed the high-risk nature of the industry, a gamble whether breeding for sale or personal racing success. Up to a third of mares would not foal successfully, some foals would be unsound, and some foals would not find a buyer, while a mare was a depreciating asset. In 1925, for example, of the 5,846 mares indexed in the Stud Book, 1,528 were barren and a further 112 slipped their foals. There was an early death rate of some 20 per cent of foals, and a further 20 per cent did not reach the sales. Research on nineteenth-century breeding has suggested that a majority of breeders did not take such costings into account and actually made a loss, and the same may have been true of the interwar years, when taxes were higher. ${ }^{21}$

Vamplew argues that in the 1920s the cost of raising a thoroughbred yearling, including costs attributed to the mare, was between $£ 200$ and $£ 300 .{ }^{22}$ To this should be added the covering fee for the stallion, and the stud fee of a more fashionable stallion, whose offspring were winning races and whose yearlings had more chance of achieving higher prices, was likely to be over $£ 100$. Each yearling sold had to shoulder an equal proportion of the stud fees, capital expenditure, charges and overheads of the stud. It should also be remembered that mares needed to be systematically replaced. In addition there was the high and growing burden of taxation. For studs to make a profit over time, there needed to be high profits in some years to offset the inevitable losing years.

The apparently profitable average yearling prices concealed potential problems for breeders. interwar specialists were well aware that breeding was 'a lottery', and that there was 'not the slightest doubt that very many ... lose money over breeding livestock'. ${ }^{23}$ In 1930 and 1931 many of the auctioned yearlings realised less or very little more than the stallion fee alone. So most breeders lost money. In the more favourable year of 1925, the 1,027 auctioned yearlings raised an aggregate sum of $£ 613,078$, representing an apparent mean poten-

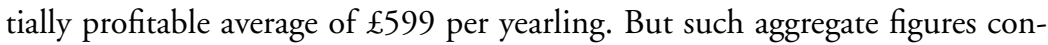
cealed problems. Of the 'lots' (i.e. all yearlings sold) owned by particular breeders at Newmarket and Doncaster sales, more than 56 per cent sold for less than $£ 450$. Only about 20 per cent of all stallions whose offspring were auctioned achieved average prices of that figure or above. It was the large sums offered for the yearlings of these fashionable stallions like Phalaris, whose offspring regularly achieved racing success, that drove up the average. At 
Doncaster in 1938 a total of 357 yearlings were sold for a total of $£ 244,120$. But 58 of these yearlings sold for $£ 1,100$ or more, making together $£ 140,385$, or 57.5 per cent of the total. The others only averaged $£ 347$ each. At other sales, most yearlings were even cheaper.

Tattersall's auction house had a virtual British monopoly over the auction of yearlings, the main commodity in commercial bloodstock breeding, taking a 5 per cent commission. ${ }^{24}$ They dominated other bloodstock sales and from 1927 also owned Manton, one of the foremost training stables. Their regular sales, held during race weeks, acted as a social centre for racing insiders. The first lots of yearlings came up for sale at Newmarket at the First and Second July Sales, which between 1919 and 1938 averaged 237 yearlings annually, with the First July Sales the more popular of the two. Their September Doncaster Yearling Sales sold on average 318 good-quality yearlings annually. Late yearlings, and those who had not found buyers earlier, would be sold at the Newmarket First October Sales, which averaged 118 yearlings annually, although a large proportion of these would be very moderate. Far fewer yearlings were sold at Newmarket's Second October Sales and the Houghton Sales, and the December Sales had very few yearlings. In Ireland the main sales of yearlings took place at the August Dublin Sales, where usually around 400 yearlings were sold. While the catalogue always had a significant proportion of poor-class youngsters, some top Irish breeders remained loyal to Dublin, so there were always many buyers from England and elsewhere. Some Irish breeders preferred to sell their stock in England, as did James Maher, perhaps the most prominent and successful breeder of his generation, having bred classic winners and a Grand National winner. He managed an average of 2,694 guineas for his 78 yearlings sold between 1919 and his death in 1935. Another Irish breeder, Peter FitzGerald, averaged 1,454 guineas for his 101 yearlings over the same period. These were well above the auction sale's annual average.

English auction figures suggest that the 1920s were a relatively prosperous period for breeders. The eleven years for 1919 to 1929 averaged 666 guineas per yearling with particularly high prices in 1919 and 1920, and again in 1925 and 1926 , before reaching an interwar peak in 1928 . However, there were also relatively poor years from 1921 to 1923 . But the next decade saw a slump in fortunes, especially in the difficult years from 1930 to 1933, following the Wall Street Crash. Most disastrous of all was 1931, when the Bloodstock Breeders' Review admitted that the economic crisis had a 'malign influence' on the turf, especially the breeding side, and on yearling prices, although it still sounded positive, claiming a return of confidence in financial and commercial circles 
Table 7.2 Tattersall's yearling sales at Newmarket and Doncaster auctions, 1919-38

\begin{tabular}{llll}
\hline & Yearlings sold & Yield in guineas & Average in guineas \\
\hline 1919 & 623 & 431,590 & 693 \\
1920 & 709 & 516,916 & 729 \\
1921 & 679 & 355,549 & 524 \\
1922 & 722 & 367,470 & 509 \\
1923 & 744 & 369,831 & 497 \\
1924 & 712 & 470,249 & 661 \\
1925 & 731 & 564,259 & 772 \\
1926 & 748 & 545,016 & 729 \\
1927 & 753 & 516,578 & 686 \\
1928 & 780 & 653,932 & 838 \\
1929 & 725 & 499,953 & 690 \\
1930 & 672 & 300,965 & 448 \\
1931 & 675 & 212,359 & 315 \\
1932 & 613 & 217,959 & 356 \\
1933 & 676 & 259,984 & 385 \\
1934 & 681 & 409,741 & 602 \\
1935 & 723 & 412,694 & 571 \\
1936 & 741 & 414,266 & 559 \\
1937 & 761 & 345,606 & 454 \\
1938 & 714 & 340,280 & 477 \\
\hline
\end{tabular}

Source: Ruff's Guide to the Turf

following the advent of the National Government. ${ }^{25}$ Many owners sold their horses, reduced the number they had in training, or got rid of unprofitable breeding mares. There was less demand for yearlings. Even the National Stud, founded in 1915/16 thanks to the gift of the Tully Stud by Col. Hall Walker (created Lord Wavertree in 1919), which was sited in southern Ireland but run by the Ministry of Agriculture and usually ran in profit, sustained losses between 1930 and 1934, with a particularly heavy loss of $£ 21,644$ in $1931 .^{26}$

The average price of a yearling in the period from 1930 to 1938 was only 463 guineas. Prices bottomed out at 315 guineas in 1931, and 1934 and 1935 were relatively good years but even then never reached the average of the previous decade. A more detailed analysis of the average price of a yearling at the prestigious Tattersall's Doncaster Yearling Sales held during the September St Leger Week between 1917 and 1939 also indicates that bloodstock prices 
showed violent short-term variation, although this was partly due to particularly high prices occasionally paid for horses from favoured studs. In 1917 the 269 yearlings fetched a mean of $£ 413$. In 1919 the 230 yearlings' average price was $£ 1,020$ although the sixteen yearlings of the fashionable Sledmere Stud, in the East Riding, raised $£ 64,365$ of this. This was in part due to the influx of foreign buyers and war profiteers spending their money. The following year the 271 yearlings averaged $£ 1,063$, with the eight yearlings of Maher's Confey Stud raising $£ 17,010$.

Sober reflection meant that Doncaster prices fell back slowly in the next three years to bottom out at $£ 653$ in 1923 but then began rising to a new and higher peak in 1926 when 325 yearlings averaged $£ 1,115$. The contraction of British staple industries, unemployment and the General Strike had had no effect on this comparatively wealthy group of purchasers. After a slight drop back in 1927, prices rose again in 1928 when 344 yearlings raised an average of $£ 1,215$, the interwar peak. But the Wall Street Crash in 1929 saw an immediate drop in prices, and they slumped further in 1930. The financial crisis of 1931 saw average prices drop even further to their lowest interwar point, with average prices of $£ 500$ at Doncaster. From then on confidence returned only slowly. Indeed, at Tattersalls staff salaries were cut by 15 per cent in 1933 because of depressed business. ${ }^{27}$ At Doncaster average yearling prices rose slowly to reach $£ 913$ in 1934. The British market was increasingly flourishing while the Deauville Yearling Sales, the main continental competitor, stood still. However, for the next few years prices dropped steadily to a low of $£ 650$ in 1937 , reflecting disturbed international relations, the threat of war and a gloomy view of the future of French racing by some French owners who were shifting some of their stables to England. ${ }^{28}$ In 1938 the outlook seemed ominous. There were wars in Spain and China, there were misgivings about the future, and during the Doncaster Sales the British fleet was mobilised. At home unemployment was rising again, and there was still depression in many areas. Many in the industry expected a weak market. So it was surprising to many that Doncaster buyers seemed in an astonishingly complacent mood, raising the average to £684. ${ }^{29}$

Numbers involved in breeding during this period are difficult to calculate. By the 1930s winning breeders' lists giving races won and prize money gained by horses bred by them included over 600 names annually. This provides a minimum figure. Success in such lists generated competition. But not all breeders were successful. Breeders came from a variety of backgrounds, but we know more about the rich breeders like George VI, who maintained a royal stud at 
Sandringham, although transferring his mares, foals and yearlings to the reopened Hampton Court paddocks in 1936.

Studs could be highly valuable capital commodities. Lord Manton's fifteen breeding mares and foals realised 70,100 guineas on his death in 1922. Larger racing stables often maintained an ancillary stud farm. The combined racing and breeding stud of Edward Hulton was disposed of for a total of 288,380 guineas in December 1925. Breeders' collective interests were looked after by their own organisation, the Thoroughbred Breeders Association, founded in 1917 , a model for others subsequently throughout the racing world. It soon had over four hundred members. The specialist magazine devoted to the British thoroughbred, the Bloodstock Breeders' Review, was first published quarterly in 1912. This, together with the annual Racing Calendar and the General Stud Book produced every four years, both by Weatherby's, provided the background about pedigrees and racing success over different distances which breeders required. Weatherby supplemented the latter with regular returns of mares, lists of dams of winners, and other statistical records, while an annual Register of Stallions was published from 1910 onwards.

Irish horses sold regularly in Britain until 1932-33 when the British imposed punitive taxation of first 20 per cent and then 40 per cent on Irish bloodstock importations after the De Valera government repudiated liabilities respecting Land Annuities and other debts. Some Irish owners relocated their studs to England as a result. Such governmental intervention showed clearly that horseracing was a major international industry.

Britain held its position as a leading exporter of bloodstock, selling horses to the colonies, Europe, and other racing countries, although America and France were catching up rapidly. Indeed French-bred horses were being purchased for English studs by the 1930s. The American-owned and bred Battleship won the 1938 Grand National. Nevertheless, the details found in the annual supplements to the four-yearly Stud Book showed clearly the significant contribution of British stock to the export trade. Even in the early 1920s, approximately 150 mares were sold abroad annually, while a small number of stallions were also sold to support the breeding stock of countries abroad. Trade increased in volume thereafter, although reduced significantly in the early 1930s. By the year 1938, British thoroughbreds sold at auction were sent to 41 other countries. Most, but not all, had imperial associations: India took 115, South Africa 63, and Australia and New Zealand also took horses. France and the USA were by far the leading non-imperial customers. Although most thoroughbreds were of moderate quality, top-quality stallions reflected high prices. Here America 
proved a major purchaser. In 1936 the Aga Khan sold his 1930 Derby winner there for $£ 45,000$. When the 1935 Derby winner, Bahram, was sold to America in 1940 he raised $£ 40,000$. A number of commercial companies were set up to manage such international sales, including the British Bloodstock Agency Ltd, founded in 1911, which handled many interwar sales, and the joint Anglo-Irish Agency Ltd. Horses were insured during travel through Lloyds, and the more general extension of bloodstock insurance was another feature of the period. International links were fostered too by the Jockey Club, which from 1925 increasingly developed reciprocal arrangements with the racing authorities of the same group of countries for the enforcement of sentences passed on offenders.

\section{Ownership}

While within racing owners were a relatively high-status group, they received less coverage in the sporting press than horses, jockeys and trainers. Very rich owners like Lord Derby or the Aga Khan were exceptions. When press headlines like 'Great Day for Sir Abe Bailey' celebrated the success of the owner rather than the horse it was usually because a human-interest story was involved. ${ }^{30}$ Ownership was more of a hobby in Britain than in most other countries. In Britain owners contributed over half the prize money of a race in stakes, forfeits and other entry fees. This was far higher than elsewhere. The British state, almost alone of almost any country where racing was carried on, gave no public money for its encouragement until some limited income from the Tote began to be dispensed in the later 1930s.

Owners were not easily categorised. Their approaches to betting, buying, selling and running horses could be very different. They were divided into three groups: those who owned steeplechasers, the largest group who owned the more expensive flat racehorses, and the smallest group who owned both. In steeplechasing, very much the poor relation, owners in the early 1920s were supposedly divided into those horse lovers who raced one or two horses they had bred themselves, and gamblers manipulating their horses in the market. ${ }^{31}$ However, the interwar period also saw an influx of rich Americans trying to win the Grand National, and an increase in the numbers of wealthier patrons like Miss Dorothy Paget or Lord Bicester.

Flat-racing owners were a disparate group with varied social backgrounds, education, interests and occupations, and ranged from members of the royal family and aristocracy to farmers, veterinary surgeons and small businessmen. 
The royal family was not amongst the leading owners, but the monarchy's public support for racing should be seen as an important cultural marker. Its attitudes to betting, ownership and breeding varied. Edward VII enjoyed betting as much as ownership and breeding. George $\mathrm{V}$ took his responsibilities as an owner seriously, enjoyed the social life of a day's racing, was knowledgeable about breeding, but saw less appeal in betting. George VI maintained the royal stud and his racing stable, having five winners in 1939, but had no interest in betting. ${ }^{32}$

Breeding and ownership were largely inseparable. Interest in both was a pleasurable upper-class hobby, although betting among the upper classes had declined in both amount and importance. ${ }^{33}$ Sporting, social and cultural motives for involvement were all important. Titled names dominated the winning owners' lists, as they did the Jockey Club. Lord Derby, one of the most successful owners of the period, with Lord Rosebery best represented the traditional racing aristocracy. Some of this group, like Lord Zetland, regretted that racing was growing ever more commercialised and businesslike, and wondered ruefully whether 'that spirit of good sportsmanship of which we are so proud plays as prominent a part in racing as we would like to think it does'. ${ }^{34}$ Such local magnates often raced for racing's sake, and patronised their local meetings. Death duties were however increasingly having an effect on their involvement. The dukes of Richmond had a long-standing interest in the turf in general and in Goodwood in particular, but the eighth duke was so crippled by the crushing death duties which had to be paid when his father died that he could not afford to launch out as an owner on a big scale. He only had a few racehorses, and they were not of much account.

These long-standing aristocratic families were ever-increasingly joined in racing by newly-titled owners from lower-status backgrounds such as Lord Woolavington (a Scots-Canadian clerk and agent who became a wealthy whisky distiller), Lord Glanley (a former Cardiff clerk who founded a shipping company) and Sir Blundell Maple (the 'furniture king'). This new plutocratic meritocracy found racing suited to their ostentatious ambitions. They were often extremely wealthy. Lord Woolavington, for example, left estate of $£ 7,150,000$. Some envied the upper-class world, others enjoyed the surviving traditions of courtesy and respect with which trainers and jockeys treated them. Some loved horses, and spoke about them emotionally. Some were more dispassionate but very knowledgeable about racing and breeding. Others just gained pleasure from 'looking over their horses in the paddocks and paying an occasional visit to their training quarters'. ${ }^{35}$ Some had a sentimental, sporting and irrational 
approach. Certainly they valued their involvement with racing highly. Lord Wavertree left his racing cups and trophies, together with his pictures of horses, to the Corporation of Liverpool.

It was wealthy owners who most often entered their horses for those races like the Derby with the largest money and status prizes. They could meet the very high entry fees, and had the cash and confidence to enter their yearlings for the classic races two years away before any evidence of their form. They could afford to get their breeding mares covered by the most fashionable stallions, buy the most well-bred yearlings at auction, have their horses trained by the top trainers and ridden by the top jockeys. They might even appoint a racing manager to supervise their interests. One usually reliable source suggests this alone could cost $£ 2,000-£ 3,000$ a year. ${ }^{36}$ All this increased chances of success, at a high financial cost, since their stud farms would, like their incomes, be taxed. In many years they would be unsuccessful, a fate to be accepted, as part of the challenge and risk of racing. The Aga Khan spent 'a conservative estimate of $£ 250,000$ a year' on his racing, while Sir Abe Bailey was thought to have spent over a million pounds in total on his British racing involvement. ${ }^{37}$

As a group wealthy owners were by far the most regularly successful in winning the top races. Titled owners dominated the winning owners' tables in terms of prize money won. Rosebery, for example, was a highly successful owner, winning the Derby twice, and at one time or another won virtually all the chief flat race races. As a breeder he successfully aimed to produce classic winners and high-calibre stayers at his Mentmore Stud. He was the president of the Thoroughbred Breeders' Association and a senior steward of the Jockey Club. ${ }^{38}$ The studs and racing stables of Lord Derby, Lord Woolavington, Lord Astor and the Aga Khan were also particularly prominent in winning Classic races. Such races, covering distances between a mile and a mile and a half, required a horse which had some of the skills of the sprinter, running races of less than a mile, and some of the stayer going in for races of 2 miles or more. It was hugely difficult to breed a horse with sprinting and staying power. Only a few individuals managed it more than once or twice. Although Lord Astor never won a Derby, his horses' other Classic successes ensured that his stable regularly paid its way. He was usually near the top of the table of winning owners. In 1925 he topped the list with prize money of $£ 35,723$ from seven winning horses, and in most other years his prize money was in five-figure sums.

He was a rare exception. Even richer owners found it very difficult to be consistently successful. Racing fortunes fluctuated violently from year to year. Sir 
Hugo Cunliffe-Owen won $£ 11,204$ in 1921 and $£ 24,292$ in 1938 , yet only $£ 1,338$ in 1925 from very similar-sized racing studs. Sir Abe Bailey won $£ 15,648$ in 1926, $£ 23,279$ in 1935 and $£ 17,323$ in 1938, yet only $£ 1,423$ in 1932 .

Some rich owners maintained their own studs, others purchased their horses as yearlings. Some bought horses with proven expertise, either to race from, or as stallions for breeding. Such stallions were extremely costly. By contrast, the highest price paid for a steeplechaser was 10,500 guineas, paid for Silvo in 1925 by Mr Midwood. Even if such costs were ignored, for most owners the costs of having their horses trained and raced each year exceeded the prize money they would win. Annual training costs were probably around $£ 400$ per horse even at the start of the century, when trainers charged $£ 3$ or more a week just for basic training itself, and by shortly after the First World War the standing charge for training a horse for a week was between 4 guineas and $£ 510$ s, plus further cash presents and bonuses to trainer, jockey and stable lads, veterinary charges, shoeing, transport and entry fees to races. ${ }^{39}$ The Trainers' Federation, to which many trainers belonged, established minimum fees. ${ }^{40}$ Top steeplechasing trainers were charging about 4 guineas a week in the 1930s, with small trainers charging a great deal less. ${ }^{41}$ By the 1930 s H. S. Persse, a well-known trainer, estimated that the full cost of keeping a horse in training for a year was at least $£ 450$

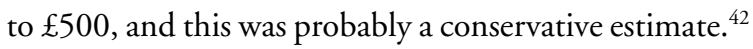

Owners' chances of ever winning were quite limited. In flat racing published lists suggest that on average only about 600 owners, of the c. 2,500 owners who had registered their racing colours for flat racing, ever won a race each year. Of all horses put into training, about five out of six never won under Jockey Club rules: they were too slow, too unsound or too lazy. Of those winning owners listed in Ruff's Guide between 1932 and 1935, only about 25 per cent covered Persse's estimated cost of keeping their winning horses in training each year, and this takes no account of any horses they had in training which failed to win a race. Other owners' horses never won.

So why were owners in racing? They entered for a range of reasons. Lord Derby, who came from a long-standing racing family, simply enjoyed the pleasure of breeding and racing his horses at top-class events. Owners loved to see their horse win. The 'thrill' of winning was almost a cliché in racing. His biographer believed that the greatest thrill of Lord Rosebery's life was when his home-bred horse Blue Peter won the 1939 Derby. ${ }^{43}$ The politician Lord Stanley said his winning of the Ascot Cup in 1936 had given him 'the greatest thrill' he would probably ever have. ${ }^{44}$ Quintin Gilbey suggested that many enjoyed the meetings and found they derived 'a greater thrill from it than from any other 
sport'. ${ }^{45}$ Some, like George VI, simply inherited a stud and continued to race. Some, even if relatively unsuccessful, just enjoyed it as a pastime. Lord Wyfold took a keen interest in his small stud, and gave real thought to the mating of his mares, whose produce he usually raced, as did Lord Cawley, 'a breeder of thoroughbreds in a small way, merely as a hobby'. ${ }^{46}$ The seventh marquis of Londonderry (1878-1949) maintained a racing stud at Wynyard throughout the interwar years, and raced his own stock. He and his wife enjoyed following the successes and failures of their breeding stud, keeping it well archived, with accounts, records of pedigrees, photographs of runners, newspaper clippings and cuttings of their occasional winners. ${ }^{47}$ The producer and actor Tom Walls, who also trained horses at Epsom, had reduced his string to a mere four after a hunting accident. He won the Derby with his own horse April the Fifth in 1932, exclaiming in his excitement, 'By gad! I've lived for this'. The three thousand plus begging letters he received subsequently were not unusual. ${ }^{48}$

Some owners entered racing for the social prestige and cultural capital it offered, and to an extent could target these attempts since different races and courses offered different levels of prize money, upper-class attendance and associated prestige. Racing at upper-class Ascot was very different to racing at the more artisan-attended Manchester course. The prize money offered for the Classic races at Newmarket, Epsom and Doncaster was far higher than prize money at Yarmouth or Beverley. Flat racing was more prestigious than National Hunt meetings, while within National Hunt the Aintree Grand National was far more prestigious than Tenby or Sedgefield. Prestige of winning had to be managed, and some paid highly for social advancement.

Top owners had opportunities to socialise at a number of formal occasions during the year, even if they were not members of the sport's governing organisations. Winning a Classic could involve the owner in a wide variety of 'society' associations, ceremonial and presentational aspects. For example, the Jockey Club Epsom Derby celebration dinner in 1935 was held in Buckingham Palace, with the table decorated with the winning owner's colours. He was congratulated by the king and queen, and the king proposed the toast. Another key event was the Derby lunch at the London Press Club, where owners would often discuss publicly their views of the chances of their horses, although often denying any real knowledge. The sixth earl of Rosebery claimed that he 'always turned to the newspapers when he wanted to know what chance any of his horses had of winning. ${ }^{49}$ Another social occasion was York's November or December Gimcrack dinner. Speeches for such events show that it was expected that winning owners of the Gimcrack race would accept their success modestly, 
ascribing it to the horse, trainer and jockey, or to 'good luck', rather than claiming it personally.

Most owners had great respect for leading trainers and jockeys and their expertise. When Lord Stanley won his Ascot Gold Cup, even in the heat of the moment he told reporters, 'Whatever you say, do not forget to give full credit to Leader for turning the mare out in such wonderful condition and to Perryman for riding such a grand race'. ${ }^{50}$ The 'luck' theme, and the respect shown for jockeys, emerges clearly in interviews given by the Aga Khan after Bahram won the 1935 St Leger, in which he not only praised the horse and jockey, but also mentioned Freddy Fox, who was to have ridden the horse but was injured the previous day: 'I cannot forget Fox in our hour of victory. I am so sorry at the bad luck which prevented him riding, I am going to the nursing home to see him. ${ }^{51}$

Over-boastful, cocky or smug behaviour by owners was always seen as inappropriate. If possible winning and losing had to be treated just the same, and winning had to be celebrated modestly. When, for example, Mrs G. B. Miller became the first woman owner of a Derby winner (Mid-day Sun) in 1937 she was interviewed by the Daily Sketchreporter who asked her what it felt like. She reportedly simply replied that it was all 'an awful fuss'. When it was pointed out to her that it was a national event and millions of people were celebrating, she asked, 'Celebrate? Does one celebrate? We are having dinner in the ordinary way'. ${ }^{52}$

Most owners did not expect to make money out of racing. At the same time, however, there was always concern to reduce its costs. Most owners always hoped for some financial return. The jockey Snowy Shepherd remembered one millionaire owner whose horse won the Birmingham Cup and 'sent it back and had the money' instead. ${ }^{53}$ Owners made constant complaints about miserly prize money and exorbitant costs in the press, at dinners and elsewhere. In a letter read at York's Gimcrack dinner in 1936, for example, Sir Abe Bailey complained that owners spent their own money to provide racing for the public. He compared the entrance and forfeit money English owners had to pay with South Africa, where it cost $£ 1$ to race for a stake of $£ 400$ or $£ 500 .{ }^{54}$ Lord Harewood's 1937 Gimcrack speech also focused on the high cost of racing to owners. 'If', he said, 'they could do anything to assist the small owner who has got to make both ends meet it would be an advantage to racing.' He went on to say that 'rich races, which alone will enable you to take a high place in the list of owners, involve you in very high costs'. He wanted the expenses of owners to be reduced, and the business of owning horses to be made much cheaper. ${ }^{55}$

There had been many middle-class owners even in the nineteenth century, but increasing numbers of successful owners were now industrialists, financiers 
or businessmen, and many were much keener to win than simply to race. Wartime millionaires, such as Sir Arthur Black with his Grimsby trawler fleet, or shipping and meat magnate Sir William Nelson, came into racing in large numbers. Successful untitled, upper-middle-class owners also entering included the miller J. V. Rank, the two Liverpool cotton brokers David Goold and W. H. Midwood, the international financier A. Lowenstein, the Dublin match manufacturer Alex Maguire, the Belfast corn trader Mr Barnett and the Shanghai bill broker Mr Morriss. ${ }^{56}$ The pages of memorial biographies in the Bloodstock Breeders' Review provide details about their occupations, involvement in ownership, and successful horses but are less clear about motivations. We know only that George Hands, for example, was 'interested in the motor industry in Birmingham, and in one of the big hotels in Torquay', and had been 'an owner of racehorses for many years and also a breeder in a small way'. ${ }^{57}$ Officers in the armed services, turf commissioners, sporting journalists, brewers, bookmakers and trainers were other significant groups owning just a few horses but running them in the most efficient way possible. For those who could not afford the full costs of ownership, partnerships were already emerging. Buckshee, for example, trained by Vasey at Doncaster, was the property of five owners. ${ }^{58}$ The hope of the smaller owner was always 'useful horses at moderate prices' ${ }^{59}$ It was reasonably common for owners to have horses with several trainers simultaneously, matching horses to trainers. R. D. Eddleston built stables at Gainford for his horses in 1910, and bred there, but had them trained at Redcar, Ellington and Neasham. ${ }^{60}$ Bert Drage, a horse dealer and breeder, had had horses with seven or more trainers. ${ }^{61}$

National Hunt racing rarely attracted the wealthier owners, and middle-class owners were even more common here, although many owners only owned only one or two horses, sometimes bred themselves. Prize money was lower, and there was less incentive for rich owners to patronise the sport. Farmers were more likely to be involved in 'chasing than the flat.

Owners from overseas were also playing a more significant role in racing. Rich American owners increasingly bought steeplechasers as well as horses for flat racing. The Grand National was a particular target, perhaps because of the transatlantic shipping links with Liverpool. As early as 1923 the race was won by Sergeant Murphy, a horse owned by Stephen Sandford, a wealthy American Cambridge undergraduate. Other Americans included the 1926 National winner's owner, A. C. Schwartz, who had bought the horse at a very high price only three weeks before in an attempt to win the race. Owners from the British Empire also played a significant role. A key group here came from the Indian 
sub-continent. The Aga Khan, the most successful owner-breeder of the period, with studs in Ireland and France as well as in England, raced on a huge scale, and was regularly leading owner and leading breeder. He had a commercial approach to racing. He spent huge sums, but may well have profited overall. The maharajah of Kolhapur (1874-1922) spent money freely on racehorses, while Major His Highness Maharajah Vijaysinhji Chhatrasinhji (1890-1951) was a keen patron of the turf and owned the 1934 Derby winner, Windsor Lad. ${ }^{62}$ The wealthy maharajah of Rajpipla was particularly popular with racecourse crowds, partly because of his playboy lifestyle, while Ranji, the former cricketer and maharajah of Nawanagar, had a few horses in training at Newmarket. ${ }^{63}$

Racehorse ownership was not monopolised by men. Women had owned horses even in the nineteenth century, but most observers felt that the increasing numbers of women owners after 1918 was a significant change. Lord Zetland, for example, accepted that 'after the war ladies, who until that time had for the most part been content to participate ... as spectators only, took their courage in both hands and registered themselves as owners'. ${ }^{64}$ Sidney Galtrey felt that their entry had 'been on such a scale as to be stupendous' ${ }^{65}$ By the 1930s between a fifth and a quarter of all those who had registered colours with the Jockey Club were women. The percentage of female winning owners rose from 9 per cent in 1920 to 21 per cent in 1938.

Table 7.3 Social background and gender of winning flat-race owners, 1920-38

\begin{tabular}{lcccc}
\hline $\begin{array}{c}\text { No. of winning } \\
\text { military and } \\
\text { titled males }\end{array}$ & $\begin{array}{c}\text { No. of titled } \\
\text { females }\end{array}$ & $\begin{array}{c}\text { Other winning } \\
\text { males }\end{array}$ & $\begin{array}{c}\text { Other winning } \\
\text { females }\end{array}$ \\
\hline 1920 & 107 & 10 & 351 & 35 \\
1926 & 123 & 15 & 357 & 53 \\
1932 & 133 & 18 & 296 & 96 \\
1938 & 139 & 25 & 376 & 116 \\
\hline
\end{tabular}

Source: Ruff's Guide to the Turf

Some women were titled. Many came from traditional racing families, or had married into them. Lady James Douglas both bred and raced, winning the Oaks in 1919 with Bayuda. Lady Barbara Smith inherited her father Lord Coventry's stud. The rich owner Lady Zia Wernher was the daughter of Grand Duke Michael of Russia. There were others who lacked titles but were from similar 
backgrounds. One of the more famous owners of the period was the eccentric and heavy-betting Miss Dorothy Paget, whose inherited American chain-store wealth was spent on both flat and National Hunt racing. She was a daughter of Lord Queenborough. ${ }^{66}$ Viscountess Torrington, who loved horses and would do anything for their welfare, invested a fortune in a failed attempt to develop a successful racing stud.

Biographies suggest that a shared interest in racing, breeding and ownership was a feature of some middle-class marriages during the period. There were couples such as the Whitburns who had separate colours, each racing their own horses. Others were joint owners. Major J. C. Lewis and his wife 'took the keenest interest in breeding' and shared the ownership of Glenhazel, who won the 1928 Queen's Prize in her colours. ${ }^{67}$ Many women remained in racing after their husband's death. Some women, such as Mrs Beatty, the energetic wife of an American financier and mining engineer, raced even though their husbands were uninterested in the sport. Mrs Beatty's lavish expenditure was not repaid by racing success. In steeplechasing Mrs William Partridge won the Grand National with Sprig in 1927. She possessed great affection for the horse and steadfastly refused all offers to purchase him. Mrs Ambrose Clark, well-liked and respected, won the Grand National with Kellsbro' Jack in 1933, after being sold the horse by her husband for the token sum of $£ 1$.

Some owners rarely or never bet. The excitement of the course, hope of success and the occasional thrill of winning were enough. As 'The Scout' pointed out, 'it often happens that the leading owners are not concerned with betting at all'. ${ }^{68}$ He cited Lord Astor, Lord Derby and the Aga Khan as leading examples, although the latter had in earlier years been a punter. Owners were part of the racing world, and most were not immune from the excitement of betting on all horses, not just their own. Probably the majority of owners bet on their own horses when they thought they had a chance. It added spice and excitement to their racing. But few bet large amounts, although winnings could be large when odds were long. Jack Burnley, a well-known advertising industry figure, won $£ 1,000$ when his horse won the Cesarewitch in 1921 at odds of 33-1, but more normally wagered around $£ 10$. The financier Jimmy White won more than $£ 100,000$ on his horse Irish Elegance in the Royal Hunt Cup of 1919. ${ }^{69}$ The Yorkshire owner H. F. Clayton backed his horses many months before to win the Cesarewitch and Cambridgeshire in 1931 to win $£ 100,000$ to $£ 100$, and nearly succeeded. Winning a major race involved 'presents' to jockey and trainers, and other such disbursements, so the risk of backing one's horse often seemed to make sense. There were still those who ended up plunging and losing 
vast fortunes. White eventually went bankrupt. The marquis of Breadalbane had racing debts which forced much of his Scottish estates to be sold in $1921 .^{70}$

But there were also calculating owners who viewed horses as an instrument of speculation, backing their horses when they were expected to win, and laying them when they could be made sure to lose. Such gambling owners were least likely to be breeders. C. R. Acton suggested that local publicans in particular often ran their horses in selling plates or at small local low-status 'flapping tracks' not recognised by the Jockey Club where results could be more easily manipulated. ${ }^{71}$ In fact, however, owner-gamblers of all classes had similar attitudes. Sir Charles Butt, for example, was 'more interested in a coup than in the development of a racehorse', and held his trainer personally responsible for the success of his betting. ${ }^{72}$ At the small Pershore steeplechase course a jovial ownertrainer of a few insignificant horses had his 'ideal race' - 'Four runners, two I knew weren't trying, one was my own and the other I backed'. His own horse was (naturally) held back to ensure the 'right' result. ${ }^{73}$

\section{Notes}

11923 Select Committee on Betting Duty, report p. 50, Minutes of Evidence, QQ7590ff.

2 Sporting Chronicle, 29.3.1935; ibid., 22.6.1935.

3 Bloodstock breeders' review (London: British Bloodstock Agency, 1938), p. 163.

4 Lady Wentworth, Thoroughbred racing stock and its ancestors (London: Allen and Unwin, 1938).

5 William Fawcett, Thoroughbred and hunter: their breeding, training and management from foal to maturity (London: Eyre and Spottiswoode, 1934), p. 84.

6 Arthur FitzGerald, Royal thoroughbreds: a history of the royal studs (London: Sidgwick and Jackson, 1990), pp. 182-97.

7 Durham Record Office, D/Lo/F652 (9-10) Wynyard Park Stud; D/Lo/F654 accounts; D/Lo/F599 (1-10) statements of racing and other accounts.

8 Bloodstock breeders' review (1938), p. 157.

9 Fawcett, Thoroughbred and hunter, introduction, p. 73.

10 Sidney Galtrey, Memoirs of a racing journalist (London: Hutchinson, 1934), p. 250.

11 Quoted in Jack Fairfax-Blakeborough, Northern turf history vol. 3: York and Doncaster (London: J. A. Allen, 1950), p. 460.

12 Stanley Jackson, The Aga Khan: prince, prophet and sportsman (London: Odhams Press, 1952), p. 132. The Aga Khan, The memories of Aga Khan: world enough and time (London: Cassell, 1954), p. 198.

13 C. R. Acton, Silk and spur (London: Richards, 1935), p. 46.

14 For detailed discussion of such theories see Sir Charles Leicester, Bloodstock breeding (London: J. A. Allen, 1983). 
15 Captain Heath, News Chronicle racing annual (London: News Chronicle, 1938), p. 10.

16 See, for example, Miss F. M. Prior, Register of throughbred stallions (London: Horse and Hound, 1931).

17 Bloodstock breeders' review (1937), p. 227.

18 Suffolk Oral History Project, OHT 68, Mr Lancaster.

19 Daily Telegraph, 29.6.1938.

20 Alfred Watson, A great year: Lord Glanley's horses (London: Longmans Green, 1921).

21 M. J. Huggins, 'Thoroughbred breeding in the North and East Ridings of Yorkshire in the nineteenth century', Agricultural History Review, 42: 2 (1994), 115-25.

22 Wray Vamplew, The turf(London: Allen Lane, 1976), p. 191.

23 Fawcett, Thoroughbred and hunter, p. 63.

24 For Tattersall's history see V. Orchard, Tattersalls (London: Hutchinson, 1953); P. Willett, The story of Tattersalls (London: Stanley Paul, 1987).

25 Bloodstock breeders' review (1931), pp. 1-3.

26 Vamplew, The turf, p. 195.

27 Willett, The story of Tattersalls, p. 56.

28 V. R. Orchard, 'The bloodstock industry', in Ernest Bland (ed.), Flat racing since 1900 (London: Andrew Dakers 1950), p. 63.

29 See the comments in 'Bloodstock sales', in Bloodstock breeders' review (1938), pp. 124-5.

30 Sporting Chronicle, 27.6.1935.

31 Michael Seth-Smith et al., The history of steeplechasing (London: Michael Joseph, 1966), pp. 105-6.

32 Louis Wulff, 'Royalty and racing', in Bland (ed.), Flat racing, pp. 1-14. FitzGerald, Royal thoroughbreds, gives fuller details.

33 See Duke of Portland, Memories of racing and hunting (London: Faber and Faber, 1935).

34 Jack Fairfax-Blakeborough, The turf who's who (London: Mayfair Press, 1932), p. 476.

35 Arthur J. Sarl, Horses, jockeys and crooks: reminiscences of thirty years' racing (London: Hutchinson, 1935), p. 20.

36 Acton, Silk and spur, p. 173.

37 Jackson, The Aga Khan, p. 140; Captain X, Tales of the turf (London: Partridge Publishers, 1943), p. 22.

38 Obituary by John Hislop, The British racehorse (1974, p. 8.

39 Vamplew, The turf, p. 174; Eric Rickman, 'Tests imposed by classic races', in Bland (ed.), Flat racing, p. 124. Eric Rickman, Come racing with me (London: Chatto and Windus, 1951), p. 65.

40 The Times, 11.12.1919.

41 Seth-Smith et al., The history of steeplechasing, p. 119.

42 H. S. Persse, 'Training', in Earl of Harewood and P. E. Ricketts (eds), Flat racing (London: Seeley Service and Co., n.d.), p. 315. 
43 Kenneth Young, Harry, Lord Rosebery (London: Hodder and Stoughton, 1974).

44 Bloodstock breeders' review (1938), p. 162.

45 Quintin Gilbey, Fun was my living (London: Hutchinson, 1970), p. 146.

46 Bloodstock breeders' review (1937), p. 113.

47 Durham Record Office, D/Lo 1251 (D) Vol. 22 racing records; D/Lo 1750 (D) Boxes 43/8-9 Wynyard Racing Paddock.

48 Bloodstock breeders' review (1932), pp. 16-18.

49 Bloodstock breeders' review (1931), p. 17.

50 'The Scout' (Cyril Luckman), The Scout's guide to racing 1937 (London: Daily Express, 1937), p. 54.

51 Quoted in Fairfax-Blakeborough, York and Doncaster, p. 475.

52 Daily Sketch, 3.6.1937.

53 Suffolk Oral History Project, OHT 355, Snowy Shepherd.

54 Bloodstock breeders' review (1937), p. 272.

55 Bloodstock breeders' review (1938), p. 282.

56 Daily Telegraph, 26.3.1925; 24.3.1939. Seth-Smith, History of steeplechasing, pp. 128, 133.

57 Bloodstock breeders' review (1938), p. 166.

58 Nottingham's Post Tissue, 26.3.1932.

59 John McGuigan, A trainer's memories (London: Heath Granton, 1946).

60 Durham Record Office, D/Ed 17/93-102.

61 Bert Drage, Reminiscences of Bert Drage (London: David Green, 1955), p. 60.

62 Kusoom Vadgama, India in Britain: the Indian contribution to the British way of life (London: Robert Royce, 1984), pp. 121, 147.

63 Marcus Marsh, Racing with the gods (London: Pelham Books, 1968), p. 38; Bloodstock breeders' review (1933), p. 130.

64 Lord Zetland, 'Preface', in Fairfax-Blakeborough, The turf who's who, p. xix.

65 Galtrey, Memoirs of a racing journalist, p. 241.

66 Quentin Gilbey, Queen of the turf: the Dorothy Paget story (London: Barker, 1973).

67 Bloodstock breeders' review (1928), p. 167.

68 'The Scout', The Scout's guide to racing, 1937.

69 S. Theodore Felstead, Racing romance (London: Werner Laurie, 1949), p. 130; George Hamlyn, My sixty years in the ring: a racing and gambling autobiography (Hungerford: Sporting Garland, 1994), p. 82.

70 F. M. L. Thompson, Gentrification and the enterprise culture: Britain 1780-1980 (Oxford: Oxford University Press, 2001), p. 112.

71 Acton, Silk and spur, p. 259.

72 Marsh, Racing with the gods, p. 41.

73 Seth-Smith, History of steeplechasing, p. 107. 